\title{
Contextual Teaching and Learning (CTL) Model to Students Improve Learning Outcome at Senior High School of Model Terpadu Bojonegoro
}

Tamam Syaifuddin ${ }^{1}$, Luthfiyah Nurlaela ${ }^{2}$, Sukma Perdana $\mathrm{P}^{3}$

1,2,3 Universitas Negeri Surabaya, Surabaya, Indonesia

\begin{tabular}{|c|c|}
\hline 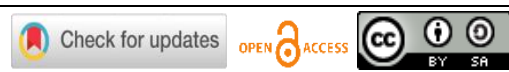 & DOI : https://doi.org/10.46245/ijorer.v2i5.143 \\
\hline Sections Info & ABSTRACT \\
\hline Article history: & The purpose of the study was to analyze the improvement of student learning \\
\hline Submitted: August 9, 2021 & outcomes with the Contextual Teaching and Learning (CTL) learning model \\
\hline Final Revised: August 26, 2021 & at Senior High School of Model Terpadu Bojonegoro in Civics subjects. The \\
\hline Accepted: September 15, 2021 & experimental study used a factorial design using pre-test and post-test. \\
\hline Published: September 30, 2021 & Collecting data using observation, documentation, and test methods. The \\
\hline Keyz & research sample was carried out in class XI of Bojonegoro Model Terpadu \\
\hline Civics subjects & Senior High School, a total of 120 students were in 4 (four) classes, each class \\
\hline CTL & consisted of 30 students. The technique used to check the validity in this study \\
\hline Learning out & is triangulation and review of informants. Based on the results of research and \\
\hline 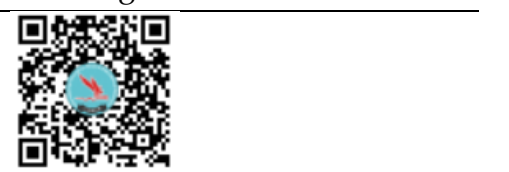 & $\begin{array}{l}\text { discussion, it can be concluded that the application of the Contextual Teaching } \\
\text { and Learning (CTL) learning model can improve Civics learning outcomes for } \\
\text { XI grade students at Senior High School of Model Terpadu Bojonegoro. } \\
\text { Increase in student learning outcomes by } 7.08 \% \text { in the second cycle. }\end{array}$ \\
\hline
\end{tabular}

\section{INTRODUCTION}

The world of education, especially Senior High School, has an important role in the development of the country. Senior high schools are prepared to be able to compete in the globalization era of the Fourth Industry (41R), so collaboration is needed between the education system, education administration, and all teachers, students, and parents. The national education system had a goal as well as important tools in achieving the goals and objectives of the nation of Indonesia in the intellectual life of the nation and to develop Indonesia (Maryanto and Saputro, 2017; Amilyana et al., 2021). Being a complete human being has several characteristics, namely being useful in educating and teaching knowledge and practice to students, teaching values of faith, attitudes, and teaching 21stcentury skills (creativity, collaboration, communication, etc), and teaching a responsible attitude towards the love of country (Amir, 2014; Cahyanti et al., 2021).

Contextual Teaching and Learning (CTL) is a comprehensive system that consists of parts connected (Wahyuningtyas et al., 2017; Indriani, 2018) If those sections are interwoven with each other, it will be an implication injunction together that exceeds the results coming to be its part separately (Haerazi et al., 2019). With the expected goal of learning in Senior High School Integrated Model of Bojonegoro, East Java - Indonesia can be reached by the desired. The implications of the above description about this research were necessary he did attempt to improve student learning outcomes by applying the model of learning Contextual Teaching and Learning (CTL).

One of the learning models can empower students, learning by using the approach of CTL (Hadiyanta, 2013; Sulfemi, 2018). Be transformation CTL, will learning atmosphere is created that gives priority to cooperation, mutual support, fun, not tedious, studying with passionate, integrated learning, using a variety of sources, active students, 
sharing with friends, students, creative teachers (Fadhilah et al., 2017). Learning takes place naturally in the form of students' work and experience, rather than the transfer of knowledge from the teacher (Laili, 2018; Susiloningsih, 2020). Students can reconstruct their knowledge, find the material concepts at hand (Setiawan et al., 2020).

Contextual Teaching and Learning (CTL) is a process of education that aims to help students see the meaning in the academic material they learned with how to connect the academic subjects they studied in the context of their daily lives, namely in the context of personal circumstances, their social and cultural. (Hyun et al., 2020; Johnson, 2007; Afni, 2020). The learning model CTL stated that learning in the CTL is not just simply sit, listen and take notes, but the learning process is experienced directly (Liski et al., 2020). Further, he Peels that CTL is a strategy that emphasizes learning to process the involvement of students in full to find material that he had learned and relate it to real-life situations (Rahayu and Cahyadi., 2019), so students are encouraged to be able to apply it in their life (Aprizani, 2016; Rofii et al., 2019). The purpose of the problem in this study is to analyze the improvement of student learning outcomes with the Contextual Teaching and Learning (CTL) learning model at the Bojonegoro Integrated Model Senior High School in Civics subjects.

\section{RESEARCH METHOD}

\section{General Background}

The factorial experimental design is the design of this study. The factorial experiment is a design that involves all independent variables to be combined with other variables (determining factor variables). The sampling technique used was random sampling. After the sample was determined from the student population of the Bojonegoro Integrated Model State High School, the sample was then tested by giving a pretest and posttest (Rustam and Fauzi, 2019). The pre-test is to determine the students' initial abilities before being treated with the CTL model, while the post-test is to determine student learning outcomes after being treated with the CTL model. The research procedure design was carried out in 2 cycles. The first cycle consisted of 2 meetings. The learning cycle scheme is presented through the following scheme (See Figure 1).

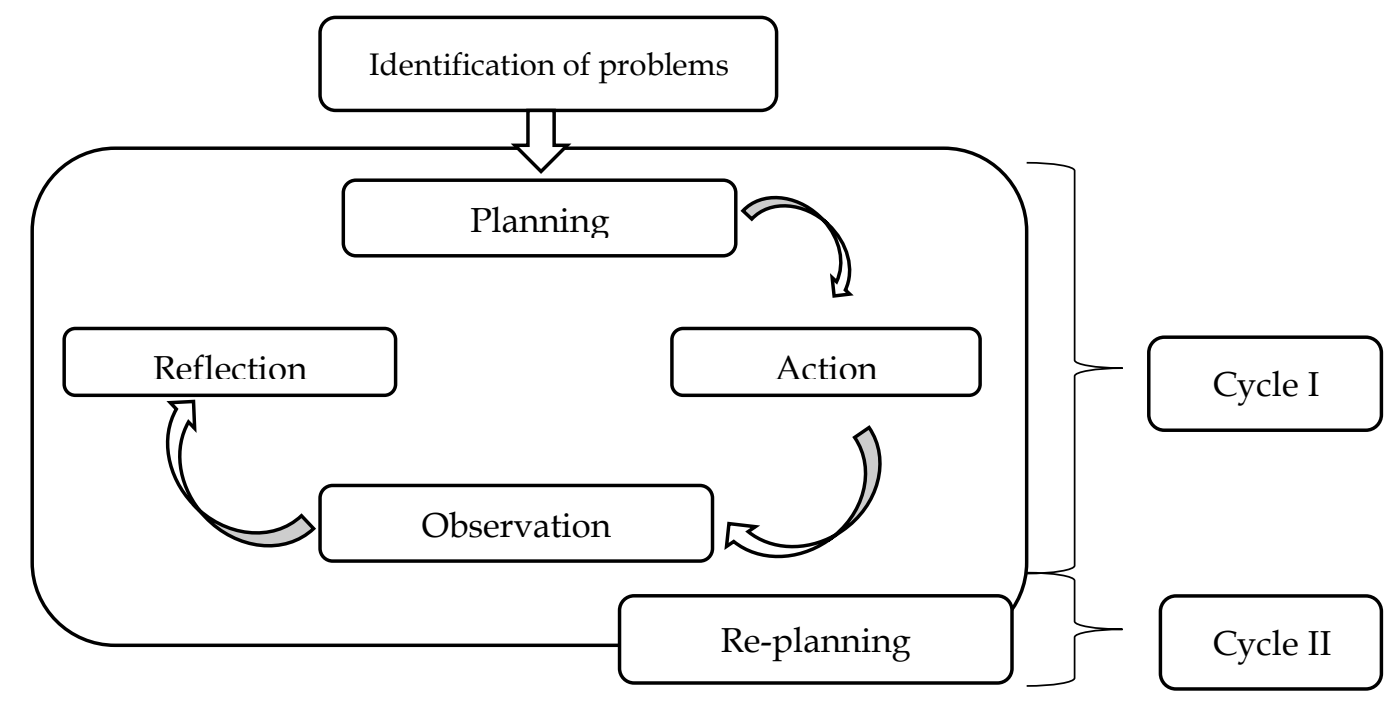

Figure 1. Flowchart of research procedure. 
Contextual Teaching and Learning (CTL) Model to Students Improve Learning Outcome at Senior High School of Model Terpadu Bojonegoro

Then the Contextual Teaching and Learning (CTL) learning model has several syntaxes, namely; 1) Student orientation to problems, 2) Grouping students to learn, 3) Guiding to investigate problems, 4) Developing and presenting work results, 5) Analyzing problem-solving and evaluating it (Sabil, 2013).

\section{Sample Research}

The characteristics of the subjects of this research were students of class XI Senior High School Model Terpadu Bojonegoro, a total of 120 students who were in 4 (four) rooms, each room with a total of 30 students. The sampling subject was taken using a stratified sampling round.

\section{Data collection}

Research data collection used observation, documentation, and test methods. Based on the calculations, all instruments were declared valid and reliable.

\section{Data Analysis}

The technique used to check the validity in this research is triangulation and review of informants. Triangulation is a validity checking technique that utilizes something other than the data for checking purposes or as a comparison against the data" (Moeleong, 2004). The triangulation technique used in this research is data triangulation and method triangulation. Triangulation of data (source) is done by collecting data about research problems from several different data sources. Method triangulation is done by digging up the same data with different methods, such as synchronizing with the results of observations or existing documents.

To maintain validity, collaboratively the data in this study was discussed with colleagues. In addition, efforts are made to pay attention to the following:

1) Observer will observe the whole sequence of events that occur in class;

2) Objectives, time limits and observation signs are clear;

3) Observation results are recorded completely and carefully; and

4) Observations must be carried out objectively.

Achievement indicators set in this study: a score of 65 or more complete because learning must be achieved at least $80 \%$ of all students. The setting of these achievement indicators is adjusted to school conditions, such as the minimum score achieved for completeness and learning to rely on teachers to learn empirically to know very well the condition of students in their class.

\section{RESULTS AND DISCUSSION}

The initial ability test is the value obtained before being given the CTL model treatment. The results of the students' initial ability tests are seen from the daily test scores in Table 1. Initial ability can be seen the average value of Civics is 65.41. 8 students scored below 65.00. While students who have reached the limit of completion, namely getting a score of 65.00 and above are 18 students. From this percentage, it means that classically it has not achieved satisfactory results because at most students only scored 65.00 and 70.00 , respectively 5 and 6 people. 
Contextual Teaching and Learning (CTL) Model to Students Improve Learning Outcome at Senior High School of Model Terpadu Bojonegoro

\begin{tabular}{cccc}
\hline \multicolumn{3}{c}{ Table 1. Initial ability test results before applying the CTL learning model. } \\
\hline Value (V) & Total (T) & V.T & Percentage \\
\hline 50 & 2 & 100 & 6,36 \\
55 & 3 & 165 & 10,50 \\
60 & 3 & 180 & 11,47 \\
65 & 5 & 325 & 20,70 \\
70 & 6 & 420 & 26,76 \\
75 & 4 & 300 & 19,10 \\
80 & 1 & 80 & 5,09 \\
Total & 24 & 1570 & $100 \%$ \\
\hline Average & \multicolumn{3}{c}{$1570: 24=65,41$} \\
\hline Classical completeness & \multicolumn{3}{c}{$16: 24 \times 100=66,67$} \\
\hline
\end{tabular}

Even though Civics learning outcomes have reached the limit of completion, teachers in the field of study continue to try to innovate learning so that Civics learning outcomes can be maintained and further improved. Initiatives taken by teachers in the field of study and supported by school principals and assisted by collaborating teacher friends, continue learning innovation by increasing the application of the CTL model, which is to encourage students to always actively look for subject matter to be discussed with friends and teachers, improve good cooperation with the aim of PAI learning outcomes can be further improved, including for other subjects.

Based on preliminary data on Civics learning outcomes, the material identifies forms of state defense efforts, it is known that 8 students score less than 65 and 16 students score above 65 . Classical completeness is $66.67 \%$. Based on these data, the class average has not yet reached the specified completion limit, as well as classically it has not reached completeness.

Based on the test results in the first cycle, it is known that the average value of Civics on the material to identify forms of state defense efforts, as many as 6 students scored below 65 (not yet completed their studies) and there were 18 students whose scores were above 65 (had completed their studies). Classical completeness has only reached $75.00 \%$ based on the data, classically it has not yet reached learning mastery. As in table 2.

Table 2. Ability test results cycle I (first) applying the CTL learning model.

\begin{tabular}{cccc}
\hline Value $(\mathbf{V})$ & Total $(\mathbf{T})$ & V.T & Percentage \\
\hline 50 & - & & \\
55 & 3 & 165 & 10,06 \\
60 & 3 & 180 & 10,97 \\
65 & 5 & 325 & 19,81 \\
70 & 6 & 420 & 25,60 \\
75 & 4 & 300 & 18,29 \\
80 & 2 & 160 & 9,76 \\
85 & 1 & 85 & 5,49 \\
Total & 24 & 1635 & $100 \%$ \\
\hline Average & \multicolumn{2}{c}{$1635: 24=68,33$} \\
\hline Classical completeness & \multicolumn{2}{c}{$18: 24 \times 100=75,00$} \\
\hline
\end{tabular}

Based on the test results in the second cycle, it is known that the average value of Civics in the material identifies forms of state defense efforts for students whose scores 
Contextual Teaching and Learning (CTL) Model to Students Improve Learning Outcome at Senior High School of Model Terpadu Bojonegoro

are below 65 are no longer available. This shows that there is a significant increase because classical learning completeness has reached $91.67 \%$. Based on these data classically, they have achieved complete learning even though there are still 2 students who have not finished because their scores are still below 65. As in Table 3 .

Table 3. Ability test results cycle II (two) applying the CTL learning model.

\begin{tabular}{cccc}
\hline Value $(\mathbf{V})$ & Total $(\mathbf{T})$ & V.T & Percentage \\
\hline 50 & - & - & - \\
55 & - & - & - \\
60 & 2 & 120 & 6,70 \\
65 & 4 & 260 & 14,52 \\
70 & 4 & 280 & 15,64 \\
75 & 5 & 375 & 20,94 \\
80 & 4 & 320 & 17,88 \\
85 & 3 & 255 & 14,24 \\
90 & 2 & 180 & 10,05 \\
Total & 24 & 1790 & $100 \%$ \\
\hline Average & & & $1790: 24=74,59$ \\
\hline Classical completeness & & & $22: 24 \times 100=91,67$ \\
\hline
\end{tabular}

Based on the results of observations, with the improvement efforts made in Civics learning materials to identify forms of state defense efforts through the application of the CTL learning model, the results achieved by students have increased. This increase can be seen from the increase in the percentage of test results obtained by students from the initial ability condition (pre-cycle) to cycle I then cycle II as shown in Tables 2 and 3 . The increase in the average value of the Civics field test results for each cycle is as follows, Table 4.

Table 4. Increase in the average score of civics study field test results in each cycle.

\begin{tabular}{ccc}
\hline Cycle & Average value & Percentage increase \\
\hline Initial Ability & 65,41 & - \\
Cycle I & 68,33 & $2,92 \%$ \\
Cycle II & 75,41 & $7,08 \%$ \\
\hline
\end{tabular}

Based on the performance indicators that have been determined that the Civics learning outcomes of class XI students of the Integrated Model State Senior High School Bojonegoro - East Java - Indonesia are completely determined if $80 \%$ of the total students score 65 and above. From the results of the action through the CTL learning model, it can be seen that the number of students who scored 65 and above reached $91.67 \%$ (22 students). Although there are still 2 students who have not completed the Civics study area, this is understandable, because the factors that affect Civics learning outcomes can come from within the students including the level of intelligence, interest in learning, motivation to learn, and others. While external factors that can affect student learning outcomes include: learning facilities, learning environment, parental guidance, and others.

The results of this study, when associated with the theory, are still relevant, according to Syaiful Sagala, (2010) learning outcomes are influenced by several factors, both internal and external. The CTL learning method includes factors that come from outside the 
Contextual Teaching and Learning (CTL) Model to Students Improve Learning Outcome at Senior High School of Model Terpadu Bojonegoro

student's self that affect student Civics learning outcomes, this is understandable, because the CTL model can make it easier for teachers during learning, where the material being studied is associated with real environmental phenomena (Juliandri, 2016). Therefore, students will be independent and always relate the material they get to environmental phenomena that occur in society (Adistiani et al., 2020). With the application of the Contextual Teaching and Learning (CTL) learning model, there will be a learning atmosphere that prioritizes cooperation, mutual support, fun, not boring, passionate learning, integrated learning, using various sources, active students, sharing with friends, critical students, creative teacher (Lotulung et al., 2018; Liski et al., 2020; Fiteriani and Solekha, 2016). During the learning process students are involved in the experimental process of observation and learning process. Students' abilities will be formed naturally during the learning process, this is because students have been trained independently in constructing experiences and problems they face. Slowly students will be trained and able to find the concepts of the subject matter being studied. Students can construct their knowledge, find their concepts of the material being faced.

\section{CONCLUSIONS}

Based on the results of the research and discussion, it can be concluded that the application of the Contextual Teaching and Learning (CTL) learning model can improve the Civics learning outcomes of class XI students of Bojonegoro Integrated Model Senior High School. Civics learning outcomes can be improved through the application of the CTL learning model to class XI students. The practical implication in this research is that the CTL learning model can be used as an effective predictor in Civics learning and as a guide in Civics learning. And future research is that it can be tested on wider students and applied with different learning media.

\section{ACKNOWLEDGEMENTS}

The research team would like to thank all those who have helped carry out this research, especially at Senior High School of Model Terpadu Bojonegoro

\section{REFERENCES}

Adistiani, S. S., Suryana, N., \& Munggaran, N. A. (2020). Pengaruh penggunaan model pembelajaran contextual teaching and learning (CTL) terhadap keaktifan belajar peserta didik pada mata pelajaran aqidah akhlak di madrasah tsanawiyah Tasikmalaya. Thoriqotuna: Jurnal Pendidikan Islam, 3(2), 181-195.

Afni, N. (2020). Contextual teaching and learning (CTL) as a strategy to improve students mathematical literacy. Journal of Physics: Conference Series, 1581(1), 1-8. https:/ / doi.org/10.1088/1742-6596/1581/1/012043

Amilyana, A. S., \& Noer, T. K. M. S. (2021). A teaching material based on science, environment, technology, and society to improve student's critical thinking skills: Synchronous and asynchronous learning during covid-19 pandemic. IJORER: International Journal of Recent Educational Research, 2(4), 372-391. https://doi.org/10.46245/ijorer.v2i4.109

Amir, D. (2014). On time and discipline in islam (analysis towards purpose of islamic education). Al-Ta lim Journal, 21(3), 220-226. https://doi.org/10.15548/jt.v21i3.107

Aprizani, Y. (2016). Improving reading comprehension using contextual teaching and learning (CTL). Studies in English Language and Education, 3(2), 170-187. https://doi.org/10.24815/siele.v3i2.4964 
Contextual Teaching and Learning (CTL) Model to Students Improve Learning Outcome at Senior High School of Model Terpadu Bojonegoro

Cahyanti, A. D., Sudibyo, E., \& Rahayu, Y. S. (2021). Effectiveness of insect encyclopedia e-book with mind mapping strategy to train students' creative thinking skills. IJORER: International Journal of Recent Educational Research, 2(4), 432-443. https:// doi.org/10.46245/ijorer.v2i4.131

Fadhilah, F., Effendi, Z. M., \& Ridwan, R. (2017). Analysis of contextual teaching and learning (CTL) in the course of applied physics at the mining engineering department. International Journal of Science and Applied Science: Conference Series 1(1), 25-32. https:// doi.org/10.20961/ijsascs.v1i1.5106

Fiteriani, I., \& Solekha, I. (2016). Peningkatan hasil belajar IPA melalui model pembelajaran contextual teaching and learning (CTL) pada siswa kelas V MI raden intan wonodadi kecamatan gadingrejo kabupaten pringsewu tahun pelajaran 2015/2016. TERAMPIL: Jurnal Pendidikan dan Pembelajaran 103-120. https://doi.org/10.24042/terampil.v3i1.1332

Hadiyanta, N. (2013). Penerapan model pembelajaran contextual teaching and learning (CTL) untuk meningkatkan hasil belajar PKn. Jurnal Kependidikan: Penelitian Inovasi Pembelajaran, 43(1). https://doi.org/10.21831/jk.v43i1.2248

Haerazi, H., Prayati, Z., \& Vikasari, R. M. (2019). Practicing contextual teaching and learning (CTL) approach to improve students'reading comprehension in relation to motivation. English Review: Journal of English Education, 8(1), 139-146. https://doi.org/10.25134/erjee.v8i1.2011

Hyun, C. C., Wijayanti, L. M., Asbari, M., Purwanto, A., Santoso, P. B., Wardani, I. G. K., \& Pramono, R. (2020). Implementation of contextual teaching and learning (CTL) to improve the concept and practice of love for faith-learning integration. International Journal of Control and Automation, 13(1), 365-383.

Indriani, R. (2018). Aktivitas guru dan siswa dalam pembelajaran matematika menggunakan contextual teaching and learning (CTL) di sekolah dasar. Pendas: Jurnal Ilmiah Pendidikan Dasar, 2(2), 261-267. http:/ / dx.doi.org/10.23969/jp.v2i2.841

Johnson, E. B. (2008). Contextual teaching $\mathcal{E}$ learning menjadikan kegiatan belajar-mengajar mengasyikkan dan bermakna. Bandung: Mizan Learning Center (MLC).

Johnson, E. B. (2008). Contextual teaching \& learning. Bandung: Mizan Learning Center (MLC).

Juliandri, D. (2016). Penerapan pendekatan contextual teaching and learning (CTL) untuk meningkatkan hasil belajar statistika. Jurnal Penelitian Pendidikan MIPA, 1(1), 1-10.

Setiawan, D., Khodijah, K., \& Mansyur, A. (2020). Implementing contextual teaching and learning (CTL) model to teach fiqh. Journal of Research in Islamic Education, 2(2), 93-105. https:// doi.org/10.25217/jrie.v2i2.1283

Laili, H. (2016). Keefektifan pembelajaran dengan pendekatan CTL dan PBL ditinjau dari motivasi dan prestasi belajar matematika. PYTHAGORAS: Jurnal Pendidikan Matematika, 11(1), 25-34. https:// doi.org/10.21831/pg.v11i1.9679

Liski, E., Jounela, P., Korpunen, H., Sosa, A., Lindroos, O., \& Jylhä, P. (2020). Modeling the productivity of mechanized CTL harvesting with statistical machine learning methods. International Journal of Forest Engineering, 31(3), 253-262. https:// doi.org/10.1080/14942119.2020.1820750

Lotulung, C. F., Ibrahim, N., \& Tumurang, H. (2018). Effectiveness of learning method contextual teaching learning (CTL) for increasing learning outcomes of entrepreneurship education. Turkish Online Journal of Educational Technology-TOJET, 17(3), 37-46. 
Contextual Teaching and Learning (CTL) Model to Students Improve Learning Outcome at Senior High School of Model Terpadu Bojonegoro

Maryanto, K. N., \& Saputro, S. P. (2017). The law politics in Indonesia's pancasila and citizenship education curriculum revitalization of 2013. Asian Social Science, 13(9), 167-173. https://doi.org/10.5539/ass.v13n9p167

Moeleong, L. J. (2004). Metode penelitian kualitatif. Bandung: PT. Remaja. Rosdakarya.

Rahayu, S., \& Cahyadi, R. (2019). Experimentation of NHT and TPS learning model using ctl approach towards mathematics learning outcomes viewed from student learning styles. International Journal of Trends in Mathematics Education Research, 2(4), 215-218. https://doi.org/10.33122/ijtmer.v2i4.140

Rofii, A., Murtadho, F., \& Rahmat, A. (2019). Needs analysis: A learning model for CTL-based academic writing. Eleventh Conference on Applied Linguistics (CONAPLIN), 254(1), 30-34. https:// doi.org/10.2991/conaplin-18.2019.221

Rustam, N. I., \& Fauzi, A. (2019). Effectiveness of integrated science textbook theme earthquake using connected model SSCS problem solving. Journal of Physics: Conference Series, 1185(1), 1-7. https://doi.org/10.1088/1742-6596/1185/1/012092

Sabil, H. (2013). Penerapan pembelajaran contextual teaching \& learning (CTL) pada materi ruang dimensi tiga menggunakan model pembelajaran berdasarkan masalah (MPBM) mahasiswa program studi pendidikan matematika FKIP UNJA. Edumatica: Jurnal Pendidikan Matematika, 1(1), 44-56. https://doi.org/10.22437/edumatica.v1i01.185

Sudjana, N. (2016). Penilaian hasil proses belajar menagajar. Bandung: Rosda Karya.

Sugiyono. (2007). Metode penelitian pendidikan. Bandung: Alfabeta

Sulfemi, W. B. (2019). Model pembelajaran contextual teaching and learning (CTL) berbantu media miniatur lingkungan untuk meningkatkan hasil belajar IPS. Edunomic: Jurnal Ilmiah Pendidikan Ekonomi Fakultas Keguruan Dan Ilmu Pendidikan, 7(2), 73-84. http://dx.doi.org/10.33603/ejpe.v7i2.1970

Susiloningsih, W. (2020). Model pembelajaran CTL (contextual teaching and learning) dalam meningkatkan hasil belajar mahasiswa PGSD pada matakuliah konsep IPS dasar. PEDAGOGIA: Jurnal Pendidikan, 5(1), 57-66. https:// doi.org/10.21070/pedagogia.v5i1.89

Wahyuningtyas, D. T., Shinta, R. N., \& Suastika, I. K. (2017). Developing addition and subtraction of integers learning moduleusing CTL (contextual teaching and learning) approach Based on curriculum 2013. Pancaran Pendidikan, 6(3), 177-182. https:/ / doi.org/10.25037/ pancaran.v6i3.97

Wahyuningtyas, D. T., Yuniasih, N., Irawan, E. B., \& Susiswo, S. (2017). Design contextual teaching and learning approach on geometry learning module. Pancaran Pendidikan, 6(4), 93-100. https:// doi.org/10.25037/ pancaran.v6i4.103

\footnotetext{
*Tamam Syaifuddin (Corresponding Author)

Universitas Negeri Surabaya, Indonesia

Jl. Raya Kampus Unesa, Lidah Wetan, Kec. Lakarsantri, Kota SBY, Jawa Timur 60213 Indonesia

Email: tamamsyaifuddin16070996005@mhs.unesa.ac.id

Luthfiyah Nurlaela

Universitas Negeri Surabaya, Indonesia

Jl. Raya Kampus Unesa, Lidah Wetan, Kec. Lakarsantri, Kota SBY, Jawa Timur 60213 Indonesia

Email: luthfiyahnurlaela@unesa.ac.id

\section{Sukma Perdana $\mathbf{P}$}

Universitas Negeri Surabaya, Indonesia

Jl. Raya Kampus Unesa, Lidah Wetan, Kec. Lakarsantri, Kota SBY, Jawa Timur 60213 Indonesia Email: sukmaperdana@unesa.ac.id
} 